\section{WALTER OWEN FILLEY}

Walter Owen Filley, Jr., passed away on March 23, 2010, at age 89 in Manchester Center, Vermont, where he had lived for seven years in an assisted living facility. Born in New Haven, Connecticut, on September 22, 1920, he attended New Haven High School and graduated from the the Choate School in 1937. He then spent a year as an exchange student sponsored by Choate in a South German school. He received his BA from Yale in 1942 before joining the Army for three years, serving mostly as a sergeant in the Counterintelligence Corps with the 2nd Armored Division in Western Europe from 1944 to 1945 .

In January 2000, Walt completed an essay entitled "A Connecticut Yankee in a Nazi School, 1937-1938," in which he recounted his experience at the Nationalsozialistische Deutsche Oberschule Starnbergersee in the village of Feldafing outside of Munich. He related how he attempted there to remain "open-minded," and to function as a "participant observer." He realized that he had become fascinated with the "social sciences" as he observed the reactivated economy, growth in armaments, and revived sense of grievance and nationalism in Germany in the late 1930s. He stood in the midst of cheering throngs in the streets of Munich when Hitler returned from Vienna in triumph after the Anschluss in 1938. For Walt, his time as an exchange student in Germany was "the crucial turning point" in his life. Later, when working in the Counterintelligence Corps in occupied Germany, Walt's earlier experience and knowledge helped in the identification of those associated with the defunct Nazi party.

After receiving his Ph.D. from Yale in 1950, Walt taught political science at the University of Michigan from 1949 to 1951, at Wesleyan University in Connecticut from 1951 to 1958 , and at the State University of New York at Binghamton from 1958 to 1987 . During these years, he participated in various civic and professional organizations, becoming president of both the New York State Political Science Association and the Northeastern Political Science Association. After retiring, he helped organize a new university-affiliated institute for lifelong learning (Lyceum) and taught and enjoyed courses until health conditions made it necessary for him to move to Connecticut and, later, to Vermont. He continued to be engaged with issues of public policy and world affairs throughout his remaining years.

Walt's main area of teaching and research was international relations. Much of his published research pertained to conflicts in multi-ethnic states, including his "Social Structure and Canadian Political Parties," which appeared in the Western Political Quarterly in December 1956. He had a lifelong interest in matters of war and peace. Walt inspired numerous students to go on to careers in academic political science and government. Both students and colleagues benefited from the qualities of warmth, generosity, and kindness that were so much a part of him.

Walt is survived by his daughter, Anne Filley; son-in-law, David Squires; grandson, Kirdan Squires; and granddaughter, Aeran Squires, all of Bondville, Vermont. He was predeceased by his wife of 43 years, Amy Salisbury Filley, and his second wife of two years, Mary Jane Hansen.

\section{Michael C. Stratford Central Michigan University}

\section{DENNIS W. HOSTETLER}

Dennis W. Hostetler of Collinsville, professor emeritus of public administration and policy analysis, died December 31, 2010, after a long illness. He was 68.

Before joining Southern Illinois University at Edwardsville in 1975 in what was then known as the Government and Public Affairs division, later part of the School of Social Sciences, Hostetler taught English and American culture for the Peace Corps at the College Moyen de Gafsa in Tunisia. He also was a teaching assistant at the University of Iowa, where he was studying for a master's and then a doctoral degree, both in political science. $\mathrm{He}$ earned the doctorate in 1974. He had received a bachelor's in philosophy in 1965 at the University of Montana. From 1972 to 1975 , Hostetler was an assistant professor, teaching American government, public administration, state and local government, political statistics, and analysis, among other subjects, all at Quincy College in Illinois.

He served as department chair of the newly named SIUE department of public administration and policy analysis from 1988 to 1996 , and also served on committees for the Chancellor's office during his career at the University. He was the author of several publications on public finance, teaching, and lesbian, gay, bisexual, and transgender (LGBT) issues; served as a consultant for state and local government agencies; and received the SIUE Teaching Excellence Award in 2003. He retired from the University in 2006.

Active in the LGBT community, Hostetler served on the boards of Parents, Families and Friends of Lesbians and Gays (P-FLAG); Services and Advocacy for Gay, Lesbian, Bisexual and Transgender Elders (SAGE) of Metro St. Louis; and Prime Timers St. Louis, an educational organization for older gay or bisexual men. Hostetler was also an avid world traveler, a competitive tennis player, a bicycle enthusiast, a member of the Gateway Squares (a gay squaredancing organization), and enjoyed playing bridge with friends. He relished intense discussions, usually about politics and life, and cherished extended family and friends.

\section{SARAH J. M. MISKIN}

It is with a heavy heart that the American Australian Association and APSA Congressional Fellowship announce the passing on Saturday, February 19, 2011, of American Australian Association/APSA Congressional Fellow Sarah Jane Merl Miskin of Canberra, Australia. Her immediate survivors include her husband Ben Miskin. Having battled with cancer which delayed her participation in the class of 2008-09, the cancer went into remission and she joined her 2009-10 class of Congressional Fellows for the Johns Hopkins School of Advanced International Studies Foreign Affairs Seminar in October 2009. The remission, however, was regrettably short-lived, and she had to return to Australia in January 2010. Throughout this tragic roller-coaster of health, and in the regrettably brief four months of her association with the fellowship, Sarah Miskin displayed a tenacity of spirit, 